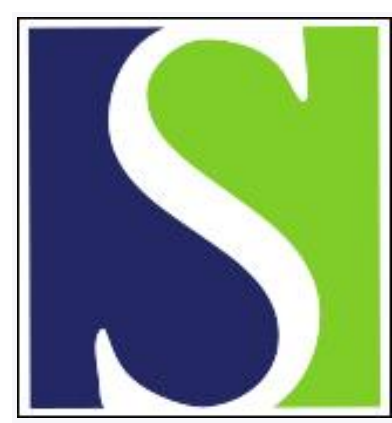

Scand J Work Environ Health 1996;22(4):274-284

https://doi.org/10.5271/sjweh.142

Issue date: Aug 1996

Ubiquitous fiber exposure in selected sampling sites in Europe by Schneider T, Burdett G, Martinon L, Brochard P, Guillemin M, Teichert U, Draeger U

Key terms: lifetime exposure; mineral fiber; organic fiber

This article in PubMed: www.ncbi.nlm.nih.gov/pubmed/8881016 


\title{
Ubiquitous fiber exposure in selected sampling sites in Europe
}

\author{
by Thomas Schneider, MSc, ${ }^{1}$ Garry Burdett, MSc, ${ }^{2}$ Laurent Martinon, MSc, ${ }^{3}$ Patrick Brochard, MD, ${ }^{4}$ \\ Michel Guillemin, PhD, ${ }^{5}$ Ulrich Teichert, MSc, ${ }^{6}$ Utz Draeger, $M D^{7}$
}

Schneider T, Burdett G, Martinon L, Brochard P, Guillemin M, Teichert U, Draeger U. Ubiquitous fiber exposure in selected sampling sites in Europe. Scand J Work Environ Health 1996;22:274-84.

\begin{abstract}
Objectives This study evaluates personal exposure to respirable inorganic and organic fibers during normal human lifetimes and assesses the order of magnitude of the contribution of inorganic fibers other than asbestos to total fiber exposure from man-made and natural sources.

Methods Four groups (suburban schoolchildren, rural retired persons, office workers, and taxi drivers), with five persons per group, were monitored for $24 \mathrm{~h}$ four times during one year. Personal sampling pumps collected airborne dust on gold-precoated Nuclepore filters. The fibers were analyzed for fiber sizes specified by the World Health Organization

Results The geometric mean concentrations ranged from 9000 fibers $\cdot \mathrm{m}^{-3}$ (office workers) to 20000 fibers . $\mathrm{m}^{-3}$ (schoolchildren) for organic fibers, and from 600 fibers $\cdot \mathrm{m}^{-3}$ (taxi drivers) to 4000 fibers $\cdot \mathrm{m}^{-3}$ (schoolchildren) for gypsum fibers. For other inorganic fibers the concentrations were around 5000 fibers $\cdot \mathrm{m}^{-3}$. The contribution of fibers with an elemental composition similar to that of man-made vitreous fibers (MMVF) was less than about one-quarter of the content of other inorganic fibers. The fiber size distributions were uniform across the groups, and the organic fibers were the longest and thinnest nonasbestos fibers.

Conclusions Lifetime exposure to fibers can be ranked as organic fibers $>$ other inorganic fibers $>$ fibers with an elemental composition similar to MMVF $>$ MMVF. Information on the biological effects of fibers is difficult to interpret for use in assessing the health risk from exposure to low levels of ubiquitous fibers, and there is a lack of knowledge on the effects of organic fibers.
\end{abstract}

Key terms lifetime exposure, mineral fibers, organic fibers, population.

The ongoing debate on the possible carcinogenic effects of fibers must include the contribution from personal exposures to indoor fibers and general population exposures. Up to now, the risk analysis for the general population has been based almost exclusively on asbestos. However, during their lifetime humans are exposed to many different types of fibers from natural and anthropogenic sources, including man-made vitreous fibers (MMVF). Skinner et al (1) have described some 420 species of natural mineral fibers, other than asbestos, and about 200 species of man-made mineral fibers (MMMF). ${ }^{8}$ A limited number of papers has been published on nonoccupational exposure to mineral fibers. General reports and proceedings of meetings have recently been published in which information on the nonoccupational exposure to fibers can be found $(2-7)$. Comparison between studies of fiber concentrations is often difficult due to, for example, use of different mea-

1 National Institute of Occupational Health, Copenhagen, Denmark.

2 Health and Safety Laboratory, Health and Safety Executive, Sheffield, United Kingdom.

3 Laboratory of Inhaled Particles Study, Mairie de Paris, France.

4 Laboratory of Occupational Medicine, Bordeaux II University, France.

5 Institute of Occupational Health Sciences, Lausanne, Switzerland.

6 Gesellschaft für Staubmesstechnik und Arbeitsschutz GmbH (GSA), Gut Vellbrüggen, Neuss, Germany.

7 Rockwool, Gladbeck, Germany.

8 MMVF will be used to indicate man-made vitreous fibers. In recent North American and Australian literature, the term SVF (synthetic vitreous fibers) is used. MMMF will be used for man-made mineral fibers. The analytical method used in the present project, scanning electric microscopy (SEM), does not allow amorphous (vitreous) fibers to be distinguished from crystalline fibers of man-made mineral origin. Thus both acronyms MMVF and MMMF will be used, depending on the exact meaning.

Reprint requests to: Mr Thomas Schneider, National Institute of Occupational Health, Lers $\emptyset$ Parkalle 105, DK-2100 Copenhagen, Denmark. 
surement objectives, methods for sampling and analysis, and counting rules. Representativity of the data for assessing the exposure may also be difficult to evaluate and the reliability of the data may not be documented. For coherence and clarity, we have summarized only the results obtained by SEM and only for mineral fibers other than asbestos in table 1. Even in this case, comparison may be questionable. The "other inorganic" fibers refer to those which are not calcium sulfate (gypsum). Some authors sometimes make another distinction by considering the "product" fibers (fibers having the same chemical composition as the product installed). In table 1 these "product" fibers have been included in the "other inorganic" category. Figure 1 shows the results for outdoor measurements. In rooms with suspended ceiling boards, average "product" fiber concentration increased to 100 fibers $\cdot \mathrm{m}^{-3}$ above atmospheric values (21). Lenvik (19) found only traces (below the detection limit of 600 fibers $\cdot \mathrm{m}^{-3}$ ) of MMMF in the air of office buildings. In the settled dust sampled in these buildings two-thirds of the MMMF, by number, had a diameter of $>3 \mu \mathrm{m}$ (able to irritate skin and eyes). Schneider et al (22) found geometric mean diameters of $3.9 \mu \mathrm{m}$ and a geometric standard deviation of 1.8 for MMVF fibers settled on room surfaces. The fibers were analyzed using polarized light microscopy. Tiesler \& Draeger (23) reported that indoor and ambient concentrations are positively correlated.

It is not known if these published results are representative for the population at large. Moreover the measurements seem to have been made almost exclusively by stationary (area) rather than by personal sampling. Recent measurements (24) have shown that a person is surrounded by a personal dust cloud, not originating from the person or the person's clothing, but from the resuspension of settled particles from his or her activities. There is no study, as far as we know, in which personal nonoccupational exposure to any type of fibers has been assessed by analyzing samples with SEM.

The possible health effects of some types of organic fibers are also under debate, and the population exposure to organic fibers needs to be determined. Synthetic and natural organic fibers include polyethylene, polypropylene, polyvinylalcohol, polyester, polyamide, polytetrafluoroethylene, carbon, and natural cellulose fibers (25). For the concentration of airborne synthetic organic

Table 1. Mineral fiber (other than asbestos) concentrations in nonoccupational situations. (ND $=$ not detected, WHO fibers $=$ fiber size as specified by the World Health Organization, ie, $D<3 \mu \mathrm{m}, L>5 \mu \mathrm{m}, \mathrm{L} / \mathrm{D}>3, \mathrm{D}=$ diameter, $\mathrm{L}=$ length)

\begin{tabular}{|c|c|c|c|}
\hline Reference & Situation & $\begin{array}{c}\text { Other fibers } \\
\text { (mean or range of } \\
\text { WHO fibers } \cdot \mathrm{m}^{-3} \text { ) }\end{array}$ & $\begin{array}{l}\text { Total inorganic fibers } \\
\text { (mean or range of } \\
\text { WHO fibers } \cdot \mathrm{m}^{-3} \text { ) }\end{array}$ \\
\hline Felbermayer \& Ussar 1980 (8) & $\begin{array}{l}\text { Urban, traffic high } \\
\text { Urban, traffic low } \\
\text { Rural } \\
\text { Unaffected area }\end{array}$ & . & $\begin{array}{r}400-4300 \\
200-5400 \\
N D-3300 \\
100-5500\end{array}$ \\
\hline Spurny \& Stöber $1981^{\mathrm{a}}(9)$ & $\begin{array}{l}\text { Urban, "clean" air } \\
\text { Urban, traffic high } \\
\text { Urban, traffic low }\end{array}$ & $\begin{array}{l}100-500 \\
400-4300 \\
200-5400\end{array}$ & $\cdot$ \\
\hline Friedrichs $1983^{a}(10)$ & $\begin{array}{l}\text { Urban/Düsseldorf } \\
\text { "Clean air" }\end{array}$ & $\cdot$ & $\begin{array}{r}60000 \\
5000\end{array}$ \\
\hline Lanting \& Den Boeft $1983^{\mathrm{a}}$ (11) & $\begin{array}{l}\text { Urban } \\
\text { Rural }\end{array}$ & $\begin{array}{l}7000 \\
8000\end{array}$ & $\cdot$ \\
\hline Altree-Williams \& Preston 1985 (12) & Indoor & $\cdot$ & $<1000-13000$ \\
\hline Iburg et al $1987^{a}(13)$ & Urban, crossing roads & $\begin{array}{l}800-2000 \\
400-1000\end{array}$ & $\cdot$ \\
\hline Dodgson et al 1987a (14) & $\begin{array}{l}\text { Indoor, new buildings } \\
\text { Indoor, old buildings }\end{array}$ & $\cdot$ & $\begin{array}{l}500 \\
100\end{array}$ \\
\hline Marfels \& Spurny $1987^{a}(15)$ & Domestic house & . & $640-5000$ \\
\hline Böckler-Klusemann et al 1989 (16) & $\begin{array}{l}\text { Administrative } \\
\text { Offices } \\
\text { Hair dresser shop } \\
\text { Emergency clinic } \\
\text { Urban }\end{array}$ & $\begin{array}{c}: \\
7 \\
700-3250\end{array}$ & $\begin{array}{c}N D-2100 \\
1700-10000 \\
N D-1350 \\
N D-4350 \\
1400-45900\end{array}$ \\
\hline Goldman \& Krüger 1989 (17) & $\begin{array}{l}\text { Urban } \\
\text { Urban, crossing roads }\end{array}$ & $\begin{array}{l}4960 \\
5890\end{array}$ & $\begin{array}{l}18160 \\
17890\end{array}$ \\
\hline Rödelsperger et al $1989(18)$ & Urban and rural & $>1000$ & $\cdot$ \\
\hline Lenvik $1992(19)$ & Offices & $\cdot$ & $<600^{b}$ \\
\hline Schnittger $1993(20)$ & Urban & 2200 & 5030 \\
\hline Unweltbundesant 1994 (4) & $\begin{array}{l}\text { Indoor } \\
\text { Outdoor }\end{array}$ & $\begin{array}{l}3180 \\
2130\end{array}$ & $\begin{array}{l}4580 \\
4990\end{array}$ \\
\hline
\end{tabular}

a References taken from Unweltbundesant (4).

- Stated as man-made mineral fibers. 


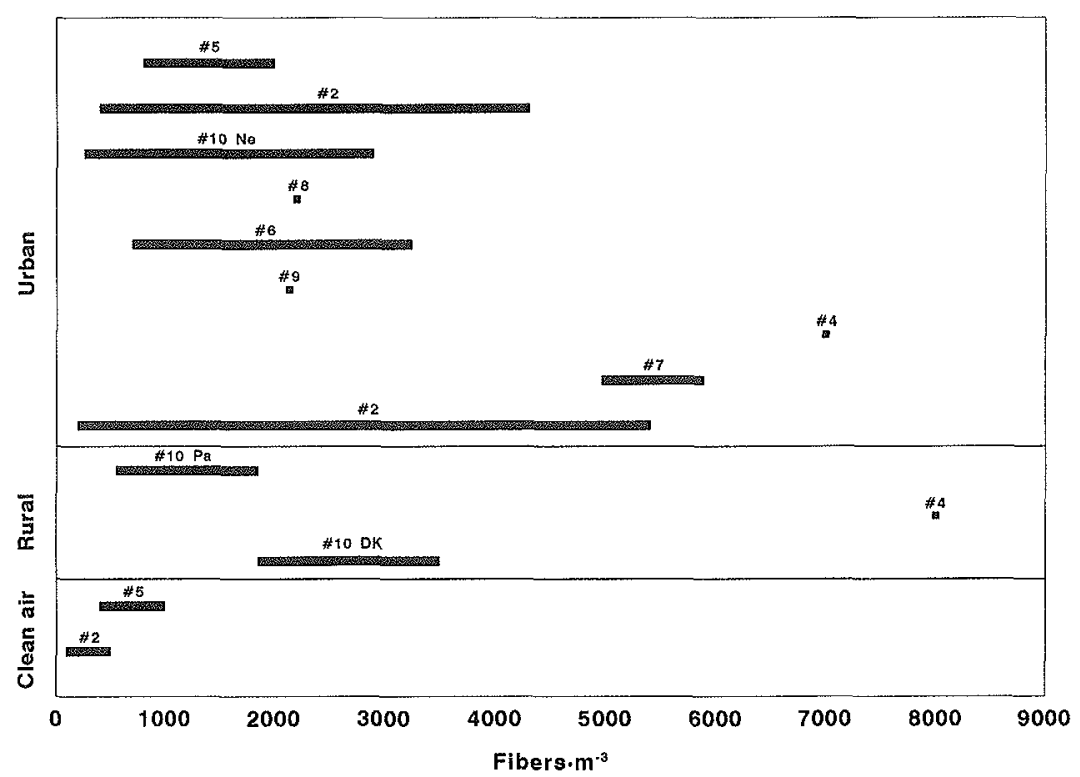

Figure 1. Mineral fiber concentrations ("other inorganic" fibers: inorganic fibers without gypsum fibers) in different outdoor situations (clean air, ie, rural and urban) (\#2 from reference 9; \#3 From reference 10; \#4 from reference 11 ; \#5 from reference 13; \#7 from reference 16 ; \#8 from reference $20 ; \# 9$ from reference 4; \#10 from this study, Ne being Neuss, Germany, Pa being Paris, France, and DK being Denmark) fibers, no information could be found other than the mention of one single measurement ( 300 fibers $\cdot \mathrm{m}^{-3}$ ) near a plant weaving carbon fibers (2). Data on natural organic fibers not related to occupational expostre are also scanty. The amount of organic fibers in indoor or outdoor air is considered to be at least as large as the amount of mineral fibers (26). This finding has been confirmed in another study (8) in which outdoor concentrations in the range of $<100$ to around 30000 fibers $\cdot \mathrm{m}^{-3}$ were found for both "other inorganic" and organic fibers. In a survey of 22 buildings for asbestos contamination (12) levels of mineral fibers of $<1000-13000 \mathrm{fi}$ bers $\cdot \mathrm{m}^{-3}$ were found. Organic fiber concentrations ranged from $<1000$ to 63000 fibers $\cdot \mathrm{m}^{-3}$. The results obtained by Schneider et al (22), using optical microscopy, support the finding that organic fibers in indoor air occur in concentrations larger than those of "other inorganic" fibers.

A small-scale study was thus performed to assess personal exposure to respirable inorganic and organic fibers (natural and man-made) during normal human lives at three geographic sites in Europe. Only a very small subsample of the population could be investigated with the resources available. The study thus does not pretend to be an exposure characterization of the population at large, but intends to give an indication of the order of magnitude of fiber exposure.

\section{Subjects and methods}

\section{Study population}

The study population should include children and adults, both employed and unemployed, in areas covering big cities, suburban areas and rural areas, but excluding persons occupationally exposed to fibers. Due to our limited resources, only the following very small subsamples were chosen: five schoolchildren aged 13-14 years from a school in suburban Paris (for practical reasons, the schoolchildren were chosen from one school and one class only), five retired persons from rural areas in Denmark (North Sealand) (the selected persons were all physically active and were living in either an apartment or a house), five office workers from one large and four small offices in the Düsseldorf-Neuss region, and five taxi drivers from the region around Düsseldorf-Neuss.

\section{Sampling}

Samples were taken at four different times within a calendar year, once for each season, beginning in the spring of 1993. Each person had to keep a diary of activities. This diary could be used for identifying possible causes of outlying analytical results. A building questionnaire describing type of building, space, floor covering, insulation, heating, presence of pets, cleaning, and do-ityourself activities was also used.

Personal sampling was carried out with gold-precoated Nucleopore filters with a pore size of $0.8 \mu \mathrm{m}$, a diameter of $25 \mathrm{~mm}$, gold-precoated and mounted in conducting filter holders, which were fitted with an extension cowl. Rotary vane pumps provided a pulsation-free, electronically regulated airflow set at $11 \cdot \mathrm{min}^{-1}$. The subjects were asked to carry the personal sampler at all times, except while in the bathroom or sleeping. Sampling usually started in the morning. For the schoolchildren sampling started at school. During the first round of measurements (spring), the filters were changed between the day and night for the schoolchildren. During sleep the sampler was positioned either close to the head in the 
bed room, if the subject could accept the pump noise, or in the living room. During stationary sampling, the filter holder was pointed downwards. The pumps were preprogrammed to shut off after $24 \mathrm{~h}$. The filters were sent by mail in their original filter holders placed in shock-absorbent containers to the analyzing laboratory.

A few (24-h) outdoor samples were taken with the same equipment. In Denmark the site of measurement was part of the national network for monitoring outdoor pollution in rural areas (Lille Valby). In France, samples were taken at a site located in Normandy (Eure), in a rural environment. In Düsseldorf samples were taken close to a one-family house situated in a housing estate near Neuss. The housing estate is surrounded by areas used for industry and agriculture. Several heavily trafficked streets and motorways are in these surroundings.

\section{Analysis}

For the analyses, we decided to use SEM for several reasons. Even though many studies assessing mineral fiber content have used transmission electron microscopy (TEM), their fiber for assessment was asbestos. SEM does not have the same capability of detecting very thin fibers, usually found for asbestos far from primary sources, and to determine the crystal structures of fibers, but it does offer some advantages. Sample preparation is simple and does not affect the particles. SEM constitutes a compromise between the amount of information obtainable by analysis and our limited resources. SEM is the method recommended for indoor and outdoor air sampling in Germany (27). Optical microscopy could have been an alternative because it is less costly, and several reports are based on this technique. However, since there was a need to distinguish between fiber types for diameters below $1 \mu \mathrm{m}$ (below which polarizing microscopy cannot be used) and down to the limit of visibility of $0.2 \mu \mathrm{m}$ of the method of the World Health Organization (WHO) (28), this method was not considered any further.

The filters were precoated with gold and analyzed by SEM according to reference 27 , with the only exception that the filters were not ashed after the sampling in order to retain the organic fibers. Jeol JSM35 and Jeol JSM6400 scanning electron microscopes were used for the analysis, both operating at a magnification of 2000 , a working distance of $15 \mathrm{~mm}$, and an accelerating voltage of $25 \mathrm{kV}$. Fibers were evaluated according to the WHO method (28). For a subsample of the filters, the lower length limit was extended downwards to $2.5 \mu \mathrm{m}$. The lower limit of fiber visibility has been estimated as $0.1 \mu \mathrm{m}$, but the boundary was not sharp (29). The analytical sensitivity was 260 fibers per cubic meter for the $2-\mathrm{mm}^{2}$ filter area evaluated.

The classification strategy followed VDI guideline 3492 (27), the fibers being categorized into asbestos, calcium sulfate (gypsum), and "other inorganic" fibers. In addition the class "organic fibers" was included. The decision criteria for the organic fibers were as follows: chrysotile if lines for manganese and silica were clear; possibly chrysotile if there were faint lines of iron, manganese, and aluminum; amphibole if the lines for silica and iron were clear; possibly amphibole if there was a faint line for manganese; gypsum if the calcium line was clear and the sulfur line was present; organic if there were no lines with an atomic number equal to or above 11 (sodium); and "other inorganic" if none of the other classifications were applicable.

If the fibers contained only chlorine, they were classified as "other inorganic", even if there was a possibility that they were organic (eg, polyvinyl chloride). Carbon fibers were classified as organic fibers, even though they were considered to be mineral fibers.

\section{Statistical analysis}

The statistical analysis was performed with MINITAB (30) using the generalized linear model. The results from the fiber counting are Poisson distributed. The concentrations thus were transformed for square root prior to the analysis in order to obtain equal variance independent of the concentration level.

\section{Results}

\section{Buildings}

A broad range of building types was included in the study. Material containing asbestos was not found in any of the buildings. Apart from the use of thermal insulation in walls and roof space, MMVF were only present in the school, which had tiles containing MMVF, and in the large office in the Neuss-Düsseldorf region, which had a suspended ceiling made of sheet metal and MMVF. There were 26 pupils in the classroom. The large office was of the open-plan type with 30 employees and 50 personal computers. The number of pet animals in the homes ranged from none to five.

\section{Fiber concentrations}

Summary statistics are shown in table 2 for the nontransformed variables of fiber length (L) $2.5 \mu \mathrm{m}<\mathrm{L}<5 \mu \mathrm{m}$. Table 3 shows the results for the fiber length of $>5 \mu \mathrm{m}$. Concentrations were also determined for fibers with a length of $>20 \mu \mathrm{m}$. None of the gypsum fibers exceeded a length of $20 \mu \mathrm{m}$, and only one asbestos fiber with a length of $>20 \mu \mathrm{m}$ was found. For "other inorganic" and organic fibers the results are given in table 4.

Asbestos concentrations were calculated by pooling the data. For all the person groups the sampled air volumes were added, the total filter areas were added, and 
Table 2. Geometric and arithmetic means and standard deviations of the exposure levels of the different groups as fibers $(2.5 \mu \mathrm{m}<\mathrm{L}<5 \mu \mathrm{m})$ per cubic meter. $(\mathrm{L}=$ length)

\begin{tabular}{lrrrr}
\hline $\begin{array}{l}\text { Type of } \\
\text { exposure }\end{array}$ & $\begin{array}{c}\text { Geometric } \\
\text { mean }\end{array}$ & $\begin{array}{c}\text { Geometric } \\
\text { SD }\end{array}$ & $\begin{array}{c}\text { Arithmetic } \\
\text { mean }\end{array}$ & $\begin{array}{c}\text { Arithmetic } \\
\text { SD }\end{array}$ \\
\hline "Other inorganic" & & & & \\
$\quad$ Schoolchildren & 9144 & 2.3 & 11856 & 8770 \\
Retired persons & 6845 & 3.8 & 12800 & 16673 \\
Office workers & 7995 & 1.6 & 8817 & 4181 \\
Taxi drivers & 11967 & 1.3 & 12292 & 3173 \\
Organic & & & & \\
Schoolchildren & 7275 & 2.0 & 9242 & 7951 \\
Retired persons & 3290 & 1.8 & 3716 & 2340 \\
Office workers & 8856 & 2.0 & 10448 & 5502 \\
Taxi drivers & 10875 & 1.9 & 12857 & 7508 \\
Gypsum & & & & \\
Schoolchildren & 4725 & 5.6 & 11564 & 11494 \\
Retired persons & 3010 & 3.8 & 5150 & 5811 \\
Office workers & 1406 & 1.9 & 1632 & 933 \\
$\quad$ Taxi drivers & 1729 & 2.2 & 2275 & 2072 \\
\hline
\end{tabular}

Table 3. Geometric and arithmetic means and standard deviations of the exposure levels of the different groups as fibers $(L>5 \mu \mathrm{m})$ per cubic meter. ( $L=$ length)

\begin{tabular}{lcccc}
\hline Group & $\begin{array}{c}\text { Geometric } \\
\text { mean }\end{array}$ & $\begin{array}{c}\text { Geometric } \\
\text { SD }\end{array}$ & $\begin{array}{c}\text { Arithmetic } \\
\text { mean }\end{array}$ & $\begin{array}{r}\text { Arithmetic } \\
\text { SD }\end{array}$ \\
\hline Other inorganic & & & & \\
Schoolchildren & 6483 & 1.7 & 7517 & 4322 \\
Retired persons & 4095 & 2.2 & 5437 & 4218 \\
Office workers & 3955 & 1.6 & 4405 & 2056 \\
Taxi drivers & 5233 & 1.9 & 6555 & 5277 \\
Organic & & & & \\
Schoolchildren & 18826 & 1.5 & 20305 & 8267 \\
Retired persons & 10927 & 1.4 & 11539 & 3888 \\
Office workers & 8857 & 1.8 & 10166 & 5123 \\
Taxi drivers & 11814 & 2.5 & 17030 & 14753 \\
Gypsum & & & & \\
Schoolchildren & 3722 & 3.6 & 6536 & 6371 \\
Retired persons & 1965 & 3.4 & 3297 & 2976 \\
Office workers & 1046 & 2.5 & 1414 & 954 \\
Taxi drivers & 597 & 2.7 & 942 & 879 \\
\hline
\end{tabular}

Table 4. Geometric and arithmetic means and standard deviations of the exposure levels of the different groups as fibers $(L>20 \mu \mathrm{m})$ per cubic meter. $(L=$ length $)$

\begin{tabular}{lcccc}
\hline Group & $\begin{array}{c}\text { Geometric } \\
\text { mean }\end{array}$ & $\begin{array}{c}\text { Geometric } \\
\text { SD }\end{array}$ & $\begin{array}{c}\text { Arithmetic } \\
\text { mean }\end{array}$ & $\begin{array}{r}\text { Arithmetic } \\
\text { SD }\end{array}$ \\
\hline Other inorganic & & & & \\
$\quad$ Schoolchildren &.$a$ &. & 39 &. \\
Retired persons &. &. & 55 &. \\
Office workers &. &. & 26 &. \\
Taxi drivers &. &. & 197 &. \\
Organic & & & & \\
Schoolchildren & 2175 & 2.4 & 3001 & 2302 \\
Retired persons & 1480 & 1.7 & 1700 & 877 \\
Office workers & 765 & 1.8 & 920 & 637 \\
Taxi drivers & 1920 & 2.0 & 2534 & 2678 \\
\hline
\end{tabular}

a Too few fibers available.

the total fiber numbers were added. This generated a meta-sample, from which the concentration was calculated in the usual manner. (See table 5.)
Table 5. Asbestos fiber concentration and 95\% confidence interval (95\% Cl) (Poisson) (fibers $\left.\cdot \mathrm{m}^{-3}\right)$ for the meta-samples. $(\mathrm{L}=$ length)

\begin{tabular}{lrrrrrr}
\hline Group & \multicolumn{2}{c}{$2.5 \mu \mathrm{m}<\mathrm{L}<5 \mu \mathrm{m}$} & & \multicolumn{2}{c}{$\mathrm{L}>5 \mu \mathrm{m}$} \\
\cline { 2 - 3 } \cline { 6 - 7 } $\begin{array}{l}\text { Fiber } \\
\text { concen- } \\
\text { tration }\end{array}$ & $95 \% \mathrm{Cl}$ & & $\begin{array}{c}\text { Fiber } \\
\text { concen- } \\
\text { tration }\end{array}$ \\
\hline Schoolchildren & 50 & $1.4-280$ & & 44 & $12-112$ \\
Retired persons & 0 & $0-390$ & & 66 & $21-154$ \\
Office workers & 0 & $0-160$ & & 10 & $0.3-58$ \\
Taxi drivers & 281 & $120-555$ & & 164 & $90-275$ \\
Taxi, excluding one & 105 & $22-308$ & & 47 & $13-120$ \\
measurement & & & & &
\end{tabular}

Table 6. Analysis of variance for fibers with $L>5 \mu \mathrm{m}$ for organic fibers also $L>20 \mu \mathrm{m}$. $(L=$ length)

\begin{tabular}{lccc}
\hline & $\begin{array}{c}\text { Degrees of } \\
\text { freedom }\end{array}$ & F-value & P-value \\
\cline { 2 - 4 } "Other inorganic" fibers & & & \\
$\quad$ Group & 3 & 3.00 & 0.037 \\
$\quad$ Season & 3 & 5.02 & 0.004 \\
$\quad$ Group $\times$ season & 9 & 1.06 & 0.405 \\
Organic fibers & & & \\
$\quad$ Group & 3 & 6.30 & 0.001 \\
$\quad$ Season & 3 & 2.33 & 0.083 \\
$\quad$ Group $\times$ season & 9 & 1.80 & 0.086 \\
Gypsum fibers & & & \\
$\quad$ Group & 3 & 11.52 & 0.000 \\
$\quad$ Season & 3 & 0.80 & 0.501 \\
$\quad$ Group $\times$ season & 9 & 0.45 & 0.905 \\
Organic fibers, L $>20 \mu \mathrm{mm}$ & & & \\
$\quad$ Group & 3 & 0.45 & 0.716 \\
$\quad$ Season & 3 & 6.95 & 0.000 \\
$\quad$ Group $\times$ season & 9 & 0.95 & 0.488 \\
\hline
\end{tabular}

\section{Statistical analysis}

The five persons within each combination (person group per season) were treated as repeat measurements. It was assumed that the results for a given person did not correlate across seasons. An initial analysis showed that there was a strong interaction between fiber type and person group. An analysis was thus performed for each fiber type separately. Only fibers with a length of $>5 \mu \mathrm{m}$ were included, and asbestos was not analyzed due to the low number of fibers detected. The result of the analysis of variance on the concentrations transformed for squareroot is given in table 6 . There was no interaction between the person group and season, except a borderline significance $(P=0.086)$ for organic fibers (length $>5 \mu \mathrm{m})$. Thus the effects of person group and season could be treated independently.

The standardized residuals for the fiber concentrations with the square-root transformation were normal (Anderson-Darling normality test in MINITAB) for the organic and "other inorganic" fibers, but not for gypsum. Six of the fiber concentration data points with normalized residuals which deviated the most from the fitted normal distribution, as estimated visually, were checked against the diaries. In the house of one schoolchild with 
high "other inorganic" and gypsum fiber concentrations, work with cement was in progress in the living room. Two low values for organic fibers for taxi drivers could not be explained. One taxi driver had a high "other inorganic" fiber concentration. This sample contained almost exclusively fibers with only a chlorine signal. A retired person with a high gypsum fiber concentration was digging out water pipe during winter and snow. All the values have been included in the analysis.

The means and standard deviations were calculated with a oneway analysis of variance (pooled estimates). They were back-transformed. The results are shown in figure 2 (seasons pooled) and figure 3 (person groups pooled).

\section{Fiber size}

The fiber concentrations calculated according to the WHO method were grouped according to diameter $(\mathrm{D}<1 \mu \mathrm{m}, 1<\mathrm{D}<3 \mu \mathrm{m})$ and length $(5<\mathrm{L}<10 \mu \mathrm{m}$, $\mathrm{L}>10 \mu \mathrm{m})$. Figure 4 shows the results.

\section{Outdoor measurements}

The results of the outdoor measurements are given in table 7 , and data concerning the "other inorganic" fibers

Table 7. Outdoor fiber concentrations as fibers $(L>5 \mu \mathrm{m})$ per cubic meter. (ND = not detected, $L=$ length)

\begin{tabular}{lrccc}
\hline Season & $\begin{array}{c}\text { Organic } \\
\text { fibers }\end{array}$ & $\begin{array}{c}\text { "Other } \\
\text { inorganic" } \\
\text { fibers }\end{array}$ & Gypsum Asbestos \\
\hline Summer 1993 & & & & \\
$\quad$ Denmark, some rain & 3450 & 1850 & 260 & ND \\
Normandy, dry & 2400 & 1850 & ND & ND \\
Neuss, clouded dry & 790 & 2900 & ND & ND \\
Winter 1993 & & & & \\
Denmark, windy & 3700 & 3500 & 5000 & ND \\
Normandy, windy, rain & ND & 550 & ND & ND \\
Neuss, rainshowers & 530 & 260 & 800 & ND \\
\hline
\end{tabular}

a) Organic
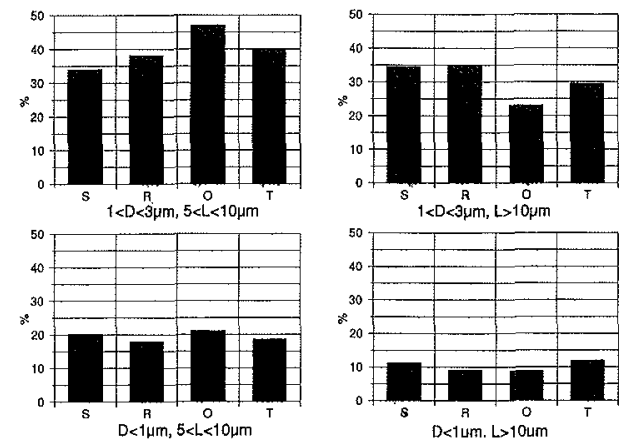

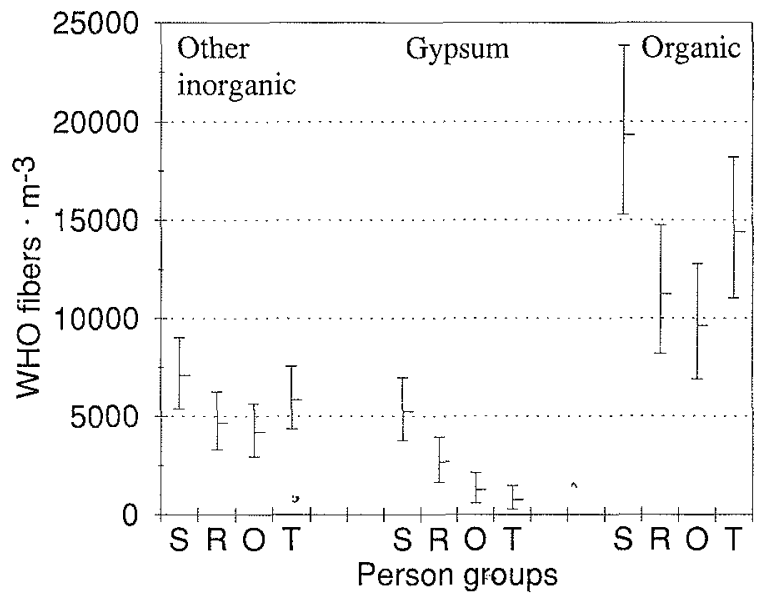

Figure 2. Fiber concentration ( $L>5 \mu \mathrm{m}$ ) for the person groups - data pooled over seasons. The results are shown as the back transformed values of the means \pm 1 standard deviation (pooled estimates) of the concentrations transformed for square root. ( $\mathrm{S}=$ schoolchildren, $\mathrm{R}=$ retired persons, $O=$ office workers, $T=$ taxi drivers, $L=$ length)

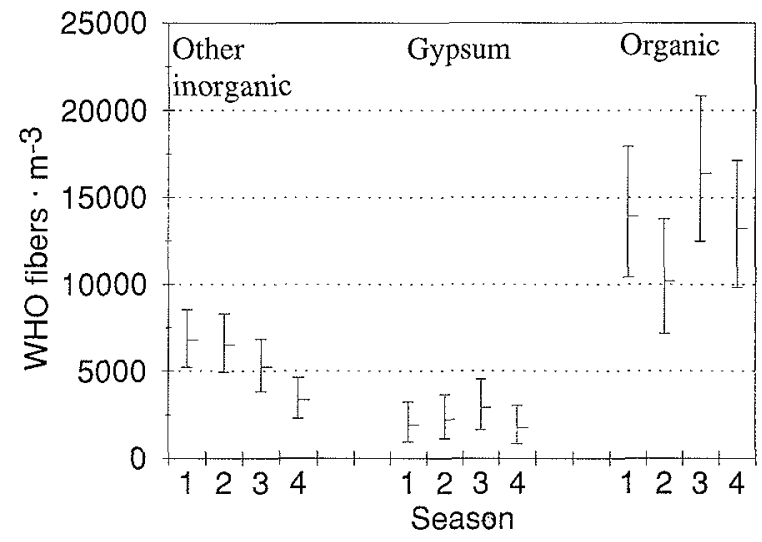

Figure 3. Seasonal variation in the fiber concentration $(L>5 \mu \mathrm{m})-$ data pooled over the person groups. The results are shown as the back transformed values of the means \pm 1 standard deviation (pooled estimates) of the concentrations transformed for square root. $1=$ spring, 2 = summer, 3 = autumn, $4=$ winter, $L=$ length)

b)
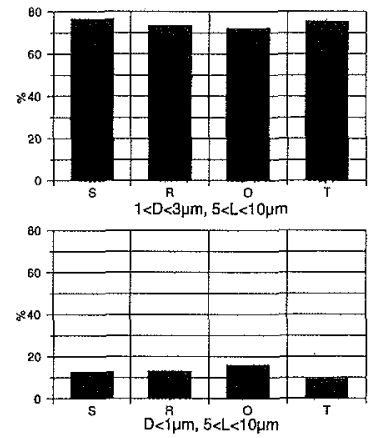

Other inorganic
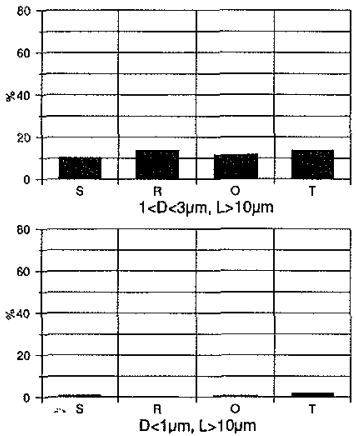

Figure 4. Size distribution of the organic (a) and other inorganic (b) fibers for the person groups - data pooled over seasons. The results are given as the percentage of fibers in the four size classes of $D<1 \mu \mathrm{m}, 1 \mu \mathrm{m}<D<3 \mu \mathrm{m}, 5 \mu \mathrm{m}<\mathrm{L}<10 \mu \mathrm{m}$, and $\mathrm{L}>10 \mu \mathrm{m}$. ( $\mathrm{S}=$ schoolchildren, $R=$ retired persons, $0=$ office workers, $T=$ taxi drivers) 
are plotted in figure 1 for comparison with results obtained by others.

\section{Quality assurance test}

All the lots of filters were prescreened according to VDI 3492 (27) and the lot could be either accepted or discarded. Actually, no lots had to be discarded. Field blanks were evaluated from each sampling exercise. After the samples had been analyzed (by GSA), one of us (GB) selected seven samples at random and recounted them on a Philips XL20 scanning electron microscope operating with a working distance of $30 \mathrm{~mm}$ and an accelerating voltage of $20 \mathrm{kV}$. There was good agreement (all 95\% Poisson confidence intervals were overlapping) between the two laboratories for a length of $>5 \mu \mathrm{m}$.

The loss of fibers during transport was estimated to be negligible. This assumption was based on experience from an interlaboratory exchange organized by VDI (König, personal communication). One fiber was found in three of nine field blanks (all giving only a chromium signal).

The hypothesis that concentrations of the organic and the "other inorganic" fibers for personal and for stationary samples (measured in an office area) could not be rejected against the alternative, according to which concentrations for personal samples are higher than for stationary samples in t-tests for the difference between the log-transformed values of stationary and corresponding personal samples.

Measurements in the breathing zone were made for one person without any contact between the filter holder and the clothing. No difference in the organic fiber concentration was found; therefore fiber abrasion from clothing was probably not a major source of contamination.

\section{Discussion}

\section{Data}

The study covered a range of building types and a range of activities. The chosen sampling methodology proved to be successful in obtaining samples for the SEM evaluation of fibers. The presence of a personal dust cloud of organic and "other inorganic" fibers could not be demonstrated for the office environment studied.

The concentration of asbestos fibers was frequently below the detection limit. This situation has been found by others also, but it is also well known that, in urban air, most of the fibers are short and thin and the concentrations are method dependent. The mean and confidence intervals thus had to be calculated from one meta-sample from each of the person groups. Only the office workers and taxi drivers had nonoverlapping $95 \%$ confidence intervals as calculated from the formed meta-samples. However, asbestos concentrations for the groups office workers, schoolchildren, and retired persons were similar. One sample (taxi driver, summer 2, person 4) was overloaded and difficult to evaluate. When this sample was removed from the data (table 5), the difference from the other person groups disappeared. No asbestos fibers were detected in the six outdoor samples. Thus there was no clear indication that taxi drivers are exposed from localized sources in the street environment, such as dust from brake linings and clutches, and possibly secondary sources built up from earlier extensive use of asbestos.

For fibers with a length of $>5 \mu \mathrm{m}$, the effect of the person group was statistically significant for explaining the differences between the measured concentrations for all three fiber types $(\mathrm{P}<0.05)$. Schoolchildren had the highest exposure. For a length of $>20 \mu \mathrm{m}$, only organic fibers were counted in sufficient numbers to allow a statistical analysis. The effect of person group was not statistically significant $(P=0.72)$. Organic fiber concentrations were in general more than twice the concentration of "other inorganic" fibers $(\mathrm{L}>5 \mu \mathrm{m})$.

Concentrations of fibers with $2.5 \mu \mathrm{m}<\mathrm{L}<5 \mu \mathrm{m}$ were similar or somewhat higher than the concentration of fibers with a length of $>5 \mu \mathrm{m}$.

For fibers with a length of $>5 \mu \mathrm{m}$, there was a significant difference between seasons for "other inorganic" fibers ( $P=0.004)$. Figure 3 shows that the "other inorganic" fiber concentrations were lowest in winter. For a length of $>20 \mu \mathrm{m}$, the season had an effect for organic fibers $(\mathbf{P}=0.00)$.

The size distributions were surprisingly uniform across the person groups (figure 4). The difference between organic and "other inorganic" fibers was as expected. The organic fibers were longer and thinner than the "other inorganic" fibers.

The outdoor concentrations in France and Denmark were measured far away from cities. The results were consistent with the assumption that wet conditions reduce resuspension and scavenging by rain reduces concentrations. The concentrations were in line with results obtained by others (figure 1). According to Schnittger (20), the concentrations of mineral fibers do not significantly differ between indoor and outdoor air. In the present investigation, however, substantially higher concentrations were found for the 24 -h average concentrations. For the schoolchildren, the spring measurements were split into day (including commuting) and night (ie, at home). A t-test was made on the difference between the log-transformed concentrations for the personal and the corresponding stationary samples for organic fibers $(\mathrm{L}>5 \mu \mathrm{m})$. The $80 \%$ confidence interval embraced zero. Back transformation implied that the day-to-night ratio of the fiber concentrations was not significantly different from one.

Since only very few outdoor samples were taken, a source apportionment could be made for the personal 
exposures. However, the outdoor results indicated that the contribution of the background concentrations, in terms of lifetime exposure, were marginal for organic and "other inorganic" fibers. The contribution of gypsum fibers can be neglected. There was no clear indication that asbestos in the street environment was a possible source of asbestos exposure.

Schnittger (20) observed some difference in the fiber types (elemental composition) between summer and winter. Moreover, an indication was found of somewhat more gypsum fibers in winter than in summer. The same trend was found in the present study.

MMVF cannot be identified by elemental composition only, as can be seen from table 8, which shows typical elemental compositions of MMVF, together with sources of non-MMVF with similar elemental composition. At the outset of the study it was assumed that the morphological criterion "lack of parallel edges" could not be used as an exclusive criterion for identification, since it had been reported (31) that significant numbers of cleavage fragments (In German: Muschelbruch) could be present. This finding was questioned as the project samples were analyzed. However, for outdoor sources, it could not be excluded that fibers are weathered and thus may show, for example, mottled surfaces. It has to be concluded that improved methods for identifying MMVF by SEM must be found.

The elemental combinations for "other inorganic" fibers, which showed a trend as estimated visually, is shown in figure 5 . The trend axis is from the rural environment (retired persons) to a strong city and traffic influence (taxi drivers). It was found that fibers not containing silicon and only containing iron are the most abundant (on a relative scale) in cities. Conversely, fibers with an elemental composition similar to MMVF, fibers containing calcium and silicon, and fibers only containing silicon were the most abundant for retired persons (rural areas). Silicon and calcium plus silicon fibers were the most frequent in the present study and were also among the most frequent in the outdoor air, as reported by Schnittger (20).

Figure 5 shows that fibers with an elemental composition as MMVF according to the definition given in reference 4 (table 8 ) constitute less than about $20 \%$ to $30 \%$ of all "other inorganic" fibers for WHO fibers (figure 5). For fibers with a length of $>2.5 \mu \mathrm{m}$ a similar trend was found. Since there was no statistically significant difference in the person group mean values for "other inorganic" fibers, concentrations of fibers with an elemental composition similar to MMVF can be estimated by multiplying the person group mean concentrations by 0.25 , the result being about 1000 WHO fibers $\cdot \mathrm{m}^{-3}$. Since MMVF would be only part thereof, this result is in agreement with findings of a recent report (32) indicating that the proportion of "product"
Table 8. Elemental composition of man-made mineral fibers, given with decreasing specificity. Other sources of fibers with similar elemental composition are also given. ( $N=$ natural rocks and soils; $V=$ volcanic eruptions; $K=$ coal burning; $M=$ waste burning; $X=$ mortar, cement, concrete, light-weight building blocks, limestone, Ca-silicates industrial minerals)

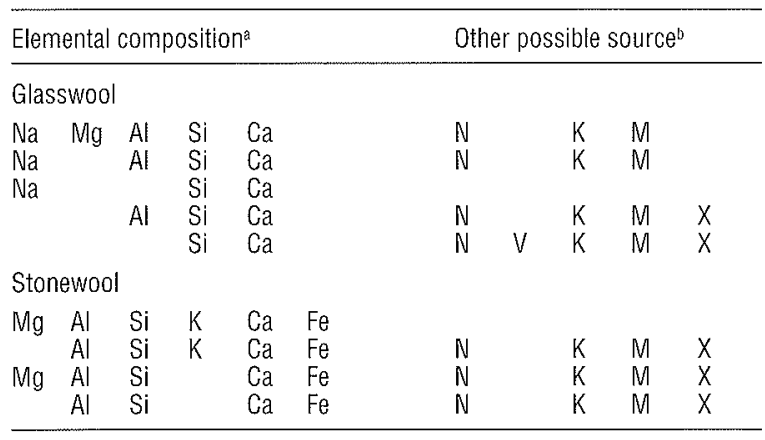

a From Umweltbundesamt (4).

- From Förster (26)

\section{Other inorganic fibers, $L>5 \mu \mathrm{m}$}

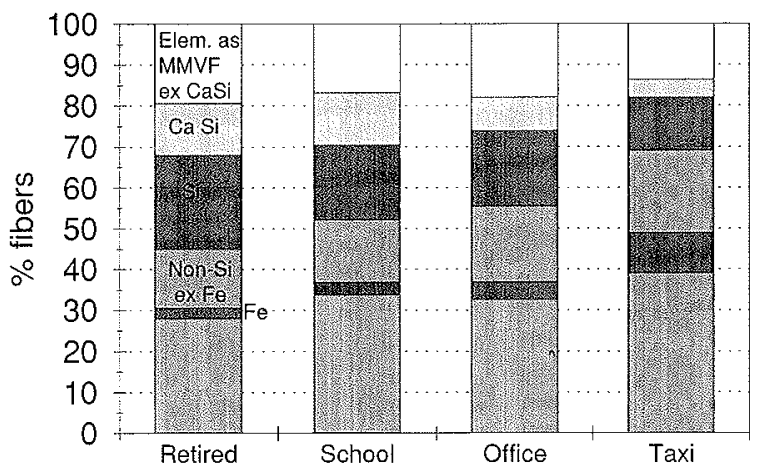

Figure 5. Relative fibers $(L>5 \mu \mathrm{m})$ with an elemental composition similar to man-made vitreous fibers excluding fibers with only calcium (Ca) and silica (Si). The order of appearance of the person groups reflects the degree of urbanization. $(\mathrm{Ca} \mathrm{Si}=$ only $\mathrm{Ca}$ and $\mathrm{Si}$ detected; $\mathrm{Si}=$ only Si detected; Non-Si = Si not detected, excluding pure (Fe) fibers; $\mathrm{Fe}=$ only $\mathrm{Fe}$ detected; $\mathrm{R}=$ retired persons; $\mathrm{S}=$ schoolchildren; $\mathrm{O}=$ office workers; $\mathrm{T}=$ taxi drivers)

fibers in rooms with MMVF materials is around $8 \%$ of the mineral fibers without gypsum.

\section{Health implications}

The health effects of very low doses of fibers on humans, as observed in this study, should be discussed according to fiber type.

Asbestos fibers. An in-depth analysis of available data on asbestos fibers has already been reported in an attempt to assess the lifetime cancer risk to building occupants (33). A conservative approach was proposed that applies linear extrapolation from effects resulting from heavy occupational exposure in the past; the risk for continuous outdoor exposure to $10 \mathrm{f} \cdot \mathrm{m}^{-3}$ (assessed by 
analytical TEM) from birth was estimated to be four premature cancer deaths (lifetime risks) per million exposed persons. Similarly, exposure to $100 \mathrm{f} \cdot \mathrm{m}^{-3}$ was associated with a risk of 40 premature cancer deaths per million exposed persons. This assessment did not take into account fiber type. Other scientists have discussed the method of risk assessment presented by the Health Effects Institute, particularly the concept of linear extrapolation (34). Finally, Valleron et al (35) concluded, after a workshop on low-dose exposure to natural and man-made fibers and the risk of cancer, that available data from indoor and outdoor low-dose levels suggest that public health risks are below reasonably measured levels.

Glass, slag and stone fibers. Human data concerning glass, slag, and stone fibers are less well defined than for asbestos. Recent up-dating of the two international occupational cohorts $(36,37)$ and the nested case-referent studies that took place in the United States $(38,39)$ did not demonstrate any clear relationship between the parameters of exposure of production workers and the numbers of lung cancer. Moreover, information concerning concomitant exposure to other respiratory carcinogens is still insufficient. Even if methodological problems could lead to an overmatching of cases and referents, the levels of exposure to MMVF observed in the present study were two orders of magnitude less than in modern fiber production plants.

Morbidity studies concerning MMVF in the same industries failed to demonstrate any chronic respiratory effects (40).

Considerable experimental data are now available concerning MMVF (41-43). They point out the importance of three major parameters that can contribute to chronic lung disease, namely, diameter, durability (or biopersistence), and dose. Very few data demonstrate dose-response relationships among in vivo experiments (inhalation and intraperitoneal injection). Even with chronic inhalation models, it is difficult to extrapolate such results for humans. It has been shown that only ceramic fibers result in excess respiratory cancer. In that situation, the no-observed effect level (NOEL) was observed with 25000000 fibers $\cdot \mathrm{m}^{-3}$ (44). However, it should be noted that the number of tumors reported per number of WHO fibers was at least five times higher for ceramic fibers than for asbestos fibers.

Organic fibers. Finally, virtually no data exist for organic fibers. However, both synthetic polymers and para-aramid fibers, have relevant experimental data available. After the publication of the controversial inhalation study (45) that used a special preparation of para-aramid fibers and showed parenchymal fibrosis and odd keratinized cysts in the lung (46), other studies proved that these fibers are biodegradable in the lungs of exposed rats. For other organic fibers like cellulose, a high biopersistence was proved (47). It must also be considered that multiple chemical treatment of organic fibers is supplied to modify the technical properties of natural fibers. As stated recently (48), there is a need to investigate these fibers.

The large amount of information on the biological effects of mineral fibers is difficult to interpret for use in the risk assessment of exposures to the low levels of ubiquitous fibers found in the present study.

\section{Conclusions}

This limited study indicated that (i) asbestos fiber concentrations can be of the order of 100 WHO fibers $\cdot \mathrm{m}^{-3}$ or lower (the SEM method may have underestimated the true concentration), (ii) lifetime exposure is ranked in the following order: organic fibers > "other inorganic" fibers $>$ fibers with elemental composition similar to MMVF > MMVF, (iii) background outdoor concentrations contribute only marginally to organic and "other inorganic" fiber exposure, (iv) schoolchildren have higher fiber exposures than other person groups, (v) better criteria for identifying MMVF need to be developed, and (vi) there is a lack of information on the effects of organic fibers, and the large amount of information on the biological effects of mineral fibers is difficult to interpret for use in the risk assessment of exposures to the low levels of ubiquitous fibers found in the present study.

\section{Acknowledgments}

The authors wish to thank the volunteers for participating in the study. The study was supported by European Insulation Manufacturers' (EURIMA) as project HSP-05.

\section{References}

1. Skinner HCW, Ross M, Frondel C, editors. Asbestos and other fibrous materials: mineralogy, crystal chemistry and health effects. New York (NY): Oxford University Press, 1988.

2. World Health Organization (WHO). Selected synthetic organic fibers. Geneva: WHO, 1993. Environmental health criteria, no 151.

3. Verein Deutscher Ingenieure (VDI). Faserförmige Stäube. Düsseldorf: VDI Verlag, 1993. VDI-berichte 1075.

4. Umweltbundesamt (UBA). Untersuchungen zur Innenraumbelastung durch faserförmige Feinstäube aus eingebauten Mineralwolle - Erzeugnissen. Berlin: UBA, 1994.

5. International Programme on Chemical Safety (IPCS). Manmade mineral fibers. Geneva: IPCS, World Health Organization, 1988. Environmental health criteria, no 77.

6. International Agency for Research on Cancer (IARC), World Health Organization (WHO). Non-occupational exposure to 
mineral fibers. Lyon: IARC, 1989. IARC scientific publications, no 90.

7. International Agency for Research on Cancer (IARC), World Health Organization (WHO). Man-made mineral fibers and radon. Lyon: IARC, 1988. IARC monographs on the evaluation of carcinogenic risks to humans.

8. Felbermayer W, Ussar MB. Forschungsbericht über "Die Belastung der Umwelt mit Abwitterungsmaterial von Asbestzementplatten". Leoben (Austria): Institut für Umweltschutz und Emissionsfragen, 1980.

9. Spurny KR, Stöber W. Some aspects of analysis of single fibers in environmental and biological samples. Int J Environ Anal Chem 1981;9:265-81.

10. Friedrichs KH. Untersuchungen zur Problematik der Messung faserförmiger Stäube. Wiss Umwelt 1983;3:125 - 46.

11. Lanting RW, Den Boeft J. Ambient air concentrations of mineral fibers in the Netherlands. In: Fibrous dusts - measurements, effects, prevention: proceedings of the VDI Kolloquium; 1982. Düsseldorf: Verein Deutscher Ingenieure (VDI) Verlag, 1983:123-8. VDI Berichte no 475.

12. Altree-Williams S, Preston JS. Asbestos and other fiber levels in buildings. Ann Occup Hyg 1985;29:357-63.

13. Iburg J, Marfels H, Spurny K. Immissionsmessungen von faserigen Stäuben in der Bundesrepublik Deutschland. Staub Reinhalt. Luft 1987;47:271-4.

14. Dodgson J, Harrison GE, Cherrie J, Sneddon E. Assessment of airborne mineral wool fibres in domestic houses. Edinburgh: Institute of Occupational Medicine, 1987. IOM-report no $\mathrm{TM} / 87 / 18$.

15. Marfels $\mathrm{H}$, Spurny KR. Indoor measurements of mineral fibers. In: Seifert B, Esdorn H, Fischer M, Rüdgen H, Wegner J, editors. Indoor air'87: proceedings of the 4 th international conference on indoor air quality and climate, August 1987; vol 1. Berlin: Institute for Water, Soil and Air Hygiene, 1987: $520-3$.

16. Böckler-Klusemann M, Fleuren A, Hoffmann E, Mutter E, Noack KH, Sonnenschein G, et al. Asbest. Dïsseldorf: Maschinenbau- und Kleineisenindustrie-Berufsgenossehschaft, 1989. Sonderausgabe des Mitteilungsblattes "sicher arbeiten".

17. Goldmann D, Krüger D. Abschlussbericht über die Messungen und Ergebnisse des Imissions-Messprogrammes Berlin (West). Berlin: Technischer Überwachungs-Verein eV, 1989. Technischer Bericht nr D-89/185.

18. Rödelsperger K, Teichert U, Marfels H, Spurny K, Arhelger $\mathrm{R}$, Woitovitz HJ. Measurement of inorganic fibrous particulates in ambient air and indoors with the scanning electronic microscope. In: Bignon J, Peto J, Saracci R, editors. Nonoccupational exposures to mineral fibres. Lyon: International Agency for Research on Cancer, 1989:361-6. IARC scientific publications, no 90.

19. Lenvik K. Man made mineral fibers in indoor air and settled dust in Norwegian office buildings. In: Lester JN, Perry R, Reynolds GL, editors. Quality of the indoor environment. London: Selper Ltd, 1992.

20. Schnittger J. Messung und Identifizierung anorganischer Fasern in der Aussenluft. In: Faserförmige Stäube Verein Deutscher Ingenieure Verlag. Düsseldorf: Verein Deutscher Ingenieure, 1993:211-31. VDI Berichte no 1075.

21. Fischer M. Benefits and Risks from MMMF. In: Kalliokoski P, Jantunen M, Seppänen O, editors. Indoor air '93: proceedings of the 6th International Conference on Indoor Air Quality and Climate, July 1993; vol 4. Helsinki: Indoor Air'93, 1993: $27-31$.
22. Schneider T, Nielsen O, Bredsdorff P, Linde P. Dust in buildings with man-made mineral fiber ceiling boards. Scand J Work Environ Health 1990;16:434 39 .

23. Tiesler $\mathrm{H}$, Draeger $\mathrm{U}$. Measurement and identification of insulation product - related fibers in contrast to ubiquitous fibers. In: Kalliokoski P, Jantunen M, Seppänen O, editors. Indoor air '93: proceedings of the 6th International Conference on Indoor Air Quality and Climate, July 1993; vol 4. Helsinki: Indoor Air'93 1993:111—6.

24. Clayton CA, Perrit RL, Pellizzari ED, Thomas KW, Whitmore RW, Wallace LA, et al. Particle total exposure assessment methodology (PTEAM) study: distributions of aerosol and elemental concentrations in personal, indoor, and outdoor air samples in a Southern Californian community. J Exposure Analysis Environ Epidemiol 1993:3:227-_50.

25. Hodgson AA. Industrial fibers: a technical and commercial review. Ann Occup Hyg 1993;37:203-10.

26. Förster H. Anorganische faserförmige Partikel in der Atmosphäre. In: Faserförmige Stäube. Duisseldorf: Verein Deutscher Ingenieure Verlag, 1993:211-31. VDI Berichte no 1075.

27. Verein Deutscher Ingenieure (VDI). VDI-Richtlinien: indoor air pollution measurement: measurement of inorganic fibrous particles: measurement planning and procedure: scanning electron microscopy. Berlin: Beuth Verlag GmbH, 1994. VDI 3492 , part 2.

28. World Health Organization (WHO). Reference method for measuring airborne MMMF. Copenhagen: WHO Regional Office for Europe, 1985. WHO environmental health report, no 4.

29. Kauffer E, Schneider T, Vigneron, JC. Assessment of manmade mineral fibre size distributions by scanning electron microscopy. Ann Occup Hyg 1983;37:469-79.

30. MINITAB. MINITAB reference manual: release 9 for Windows. State College (PA): MINITAB Inc, 1993.

31. Tiesler H, Teichert U, Draeger U. Untersuchungen zur Faserstaubbelastung durch Dämmstoffe aus Mineralwolle auf Baustellen. Zentralbl Arbeitsmed Arbeitssch Prophyl Ergonomie 1990:40:307-19.

32. Schlumm HP, Beutler M, Marfels, H. Bericht über die Untersuchung von Produkten aus künstlichen Mineralfasern (KMF) im Hochbau hinsichtlich ihrer Faserfreisetzungsverhaltens [Report on research on the fiber emission potential of MMMF products in buildings]. Filderstadt: Technischer Überwachungs-Verein Südwestdeutschland eV, 1994.

33. Health Effect Institute. Asbestos research: asbestos in public and commercial buildings: a literature review and synthesis of current knowledge. Cambridge: Health Effect Institute, 1991.

34. Sterling TD, Collett CW, Rosenbaum WL, Weinkam JJ. Comments on the Health Effects Institute/asbestos research (HEI/ AR) report: asbestos in public and commercial buildings with emphasis on risk assessment methods used. Am J Ind Med 1993;24:767-81.

35. Valleron AJ, Bignon J, Hughes JM, Hesterberg TW, Schneider T, Burdett GJ, et al. Low dose exposure to natural and man-made fibers and the risk of cancer, towards a collaborative European epidemiology. Br J Ind Med 1992; 49:606-14.

36. Marsh GM, Enterline PE, Stone RA, Henderson VL. Mortality among a cohort of US man made mineral fiber workers (1985 follow up). J Occup Med 1990;32:504-604.

37. Boffetta P, Saracci R, Ferro G, Andersen A, Bertazzi BA, Chang-Claude J, et al. IARC historical study of man-made vitreous fibre production workers in seven European countries: extension of the mortality and cancer incidence followup until 1990. Lyon: International Agency for Research on 
Cancer, 1995. IARC internal report 95/003.

38. Wong $\mathrm{O}$, Foliart D, Trent LS. A case control study of lung cancer in a cohort of workers potentially exposed to slang wool fibers. Br J Ind Med 1991;48:818 - 24.

39. Chiazze L, Watkins D, Fyar C, Kozomo J. A case control study of malignant and non malignant respiratory disease among employees of fiber glass manufacturing facility. Br J Ind Med 1992;49:326-33.

40. Hughes JM, Jones RN, Glindmeyer HW, Hammed YY, Weil $\mathrm{H}$. Follow up study of workers exposed to man-made mineral fibers. Br I Ind Med 1993;50:658 - 67.

41. Bunn WB, Bender JR, Hesterberg TW, Chase GR, Konzen JL. Recent studies of man-made vitreous fibers: chronic animal inhalation studies. J Occup Med 1993;35:101-13.

42. McConnel EE, Kamstrup O, Musselman R, Hestberberg TW, Chevalier J, Muller WC, et al. Chronic inhalation study of size-separated rock and slag wool insulation fibers in Fischer $344 / \mathrm{N}$ rats. Inhalation Toxicol 1994;6:571-614.

43. Pott F. Testing the carcinogenicity of fibers in laboratory animals: results and conclusion. In: Warheit D, editor. Fiber toxicology. San Diego (CA): Academic Press Inc, 1993:395424.

44. Health Council of The Netherlands, Dutch Expert Committee on Occupational Standards (DECOS). Man made mineral fibers (MMMF). The Hague: Health Council of The Netherlands, 1995. Publication no 1995/02 WGD.

45. Lee KP, Kelly DP, O'Neal FO, Standler JC, Kennedy GL Lung response to ultrafine kevlar aramid synthetic fibrils following 2 year inhalation exposure in rats. Fundam Appl Toxicol 1988;11:1-20.

46. Carlton WW. "Proliferative Keratin Cyst", a lesion in the lungs of rats following chronic exposure to para-aramid fibrills. Fundam Appl Toxicol 1994;23:304-7.

47. Mule H, Bellmann B. Untersuchungen der Beständigkeit von Zellulosefasern in der Rattenlunge [Investigation of the durability of cellulose fibres in the rat lung]. Hannover: Fraunhofer-Institut Toxikologie und Aerosolforschung (Fh-ITA), 1995. Final report for the Haptverband der Gewerblichen Berufsgenossenschaften.

48. Davies JMG. The need for standardised testing procedures for all products capable of liberating respirable fibers: the example of materials based on cellulose. Br J Ind Med 1993;50: $187-90$.

Received for publication: 12 July 1995 